\title{
PENINGKATAN HASIL BELAJAR TEMATIK TEMA PENGALAMANKU MENGGUNAKAN MODEL KOOPERATIF TIPE THINK PAIR SHARE (TPS) PADA SISWA KELAS II UPT. SD NEGERI 03 TABEK
}

\author{
MIRA ZULFA
}

mirazulfa03@yahoo.com

\begin{abstract}
This study aims to improve the thematic learning outcomes of the theme of my experience in class II UPT students. SD Negeri 03 Tabek uses a Think Pair Share (TPS) Type Cooperative Model. This research is a classroom action research. The research subjects were students of class II UPT. SD Negeri 03 Tabek, totaling 27 students. The research design used is the design of Kemmis and Mc. Taggart. The research was conducted in two cycles. The data collection methods used were: 1) test, 2) observation, and 3) documentation. Methods of data analysis using qualitative descriptive analysis and quantitative descriptive analysis. Indicators of research success are characterized by student activity in formulating problems, asking questions, discussing, proposing ideas, determining hypotheses, and their conclusions. In addition, the increase in student learning outcomes reached the KKM, namely 76 with a minimum percentage of $85 \%$ of the total students. Based on the results of the study, it was concluded that using the Think Pair Share (TPS) Type Cooperative Model in the My Experience Theme could improve the learning outcomes of class II UPT students. SD Negeri 03 Tabek. This is evidenced by the learning outcomes of students who reach the KKM in pre-action $48.15 \%$, in the first cycle it becomes $55.56 \%$, in the second cycle it becomes $70.37 \%$ and in the third cycle it becomes $88.89 \%$. in pre-action it was 64.44 in the first cycle to 70.37, in the second cycle it became 74.81 and in the third cycle it became 84.07.
\end{abstract}

Keywords: Thematic Learning Outcomes, Cooperative Model Think Pair Share Type.

Abstrak: Penelitian ini bertujuan untuk meningkatkan hasil belajar tematik Tema Pengalamanku siswa kelas II UPT. SD Negeri 03 Tabek menggunakan Model Kooperatif Tipe Think Pair Share (TPS). Penelitian ini termasuk jenis penelitian tindakan kelas. Subjek penelitian adalah siswa kelas II UPT. SD Negeri 03 Tabek yang berjumlah 27 siswa. Desain penelitian yang digunakan yaitu desain Kemmis dan Mc. Taggart. Penelitian dilaksanakan dalam dua siklus. Metode pengumpulan data yang digunakan yaitu: 1) tes, 2) observasi, dan 3) dokumentasi. Metode analisis data menggunakan analisis deskriptif kualitatif dan analisis deskriptif kuantitatif. Indikator keberhasilan penelitian ditandai adanya aktivitas siswa dalam merumuskan masalah, bertanya, diskusi, mengajukan gagasan, menentukan hipotesis, dan penyimpulannya. Selain itu meningkatnya hasil belajar siswa mencapai KKM yaitu 76 dengan persentase minimal $85 \%$ dari keseluruhan siswa. Berdasarkan hasil penelitian disimpulkan bahwa menggunakan Model Kooperatif Tipe Think Pair Share (TPS) pada Tema Pengalamanku dapat meningkatkan hasil belajar siswa kelas II UPT. SD Negeri 03 Tabek. Hal ini dibuktikan hasil belajar siswa yang mencapai KKM pada pra tindakan $48,15 \%$, pada siklus I menjadi $55,56 \%$, pada siklus II menjadi $70,37 \%$ dan pada siklus III menjadi $88,89 \%$.dengan nilai rata-rata siswa pada pra tindakan sebesar 64,44 pada siklus I menjadi 70,37 , pada siklus II menjadi 74,81 dan pada siklus III menjadi 84,07.

Kata kunci : Hasil Belajar Tematik, Model Kooperatif Tipe Think Pair Share. 


\section{A. Pendahuluan}

Pendidikan adalah suatu bentuk usaha manusia dalam mengembangkan ilmu pengetahuan. Pendidikan bukan hanya terdapat pada sekolah yang disebut juga dengan pendidikan formal, akan tetapi pendidikan juga dapat dilakukan secara informal yaitu dari pengalaman siswa. Pada dasarnya pendidikan formal ataupun informal sama saja karena merupakan proses dalam mencapai suatu tujuan. Sebagai pondasi dalam proses pendidikan, maka tersusun tujuan pendidikan yakni terdapat di Undang-Undang No. 20 Tahun 2003 tentang sistem pendidikan nasional yang berbunyi "Pendidikan Nasional berfungsi untuk mengembangkan kemampuan dan membentuk watak serta peradapan bangsa yang bermartabat dalam rangka mencerdaskan kehidupan bangsa, bertujuan untuk berkembangnya potensi peserta didik agar menjadi manusia yang beriman dan bertaqwa kepada Tuhan Yang Maha Esa, berakhlak mulia, sehat, berilmu, cakap, kreatif, mandiri, dan menjadi warga negara yang demokratis serta bertanggung jawab".

Belajar merupakan sebuah aktivitas manusia yang sangat penting dan akan terus menerus akan dilakukan selama berlangsungnya hidup manusia tersebut. Proses belajar merupakan proses yang bersifat internal yang terjadi di dalam diri seseorang yang sedang mengalami proses belajar. Oleh karena itu dalam proses belajar, setiap orang mendapat pengetahuan yang berbeda beda tergantung sejauh mana orang tersebut menjalankan proses belajarnya. Salah satu ciri bahwa seseorang belajar ialah adanya perubahan tingkah laku yang disebabkan oleh terjadinya perubahan tingkat pengetahuan, sikap, ataupun keterampilannya. Perubahan tingkah laku akibat proses belajar seseorang tidak akan terjadi tanpa adanya aktivitas dan usaha yang sengaja

Proses belajar juga bisa disebut dengan proses pembelajaran. Pada proses pembelajaran siswa dituntut aktif mencari, menemukan, menganalisis, merumuskan, memecahkan masalah, dan menyimpulkan masalah. Pembelajaran merupakan interaksi dua arah dari seorang guru dan siswa dimana diantara keduanya terjadi komunikasi yang intens dan terarah menuju pada suatu target yang telah ditetapkan sebelumnya. Dalam konteks ini, maka diperlukan kurikulum, dan bagaimana cara yang efektif untuk melaksanakan pembelajaran. Pembelajaran Tematik merupakan program pembelajaran yang beranngkat dari satu tema/ topik tertentu dan kemudian dielaborasi dari berbagai aspek atau ditinjau dari berbagai perspektif mata pelajaran yang biasa diajarkan di sekolah. Pembelajaran tematik juga merupakan pembelajaran yang sudah teritegrasi dari beberapa mata pelajaran seperti Matematika, Bahasa Indonesia, PKn, dan lain sebagainya. Maka dibutuhkan metode pembelajaran yang dapat membuat siswa merasa tidak cepat bosan dan menerima pembelajaran dengan baik. Akan tetapi pada kenyataannya masih banyak siswa yang belum mampu menguasai meteri dalam pembelajaran tematik ini, mungkin dikarenakan banyaknya materi yang harus mereka pahami sehingga mereka kesulitan pada materi tertentu

Permasalahan tersebut peneliti dapatkan ketika melaksanakan kegiatan belajar mengajar di kelas II UPT SD Negeri 03 Tabek pada pembelajaran tematik. KKM sebesar 76. Pada kelas II ini terdapat 27 siswa. Setelah diadakan penilaian awal (Pre test) dapat disimpulkan bahwa siswa yang mendapat nilai di atas KKM sebanyak 13 siswa dan yang mendapat nilai di bawah KKM sebanyak 14 siswa. Hal tersebut disebabkan oleh beberapa alasan. Yang pertama adalah kurang tepatnya guru dalam menggunakan metode pembelajaran. Sebenarnya guru sudah baik dalam menyajikan materi namun kurang variatif. Guru hanya menggunakan metode ceramah dalam pembelajaran tematik yang menyebabkan antusias belajar siswa kurang aktif Banyak 
siswa yang jenuh dan acuh dalam mengikuti proses pembelajaran yang mengakibatkan mereka ramai sendiri. Sehingga pemahaman siswa terhadap isi materi yang diajarkan guru tidak maksimal.

Untuk dapat meningkatkan hasil belajar siswa, selain siswa yang dituntut untuk berperan aktif, diharapkan seorang guru juga dapat berperan aktif dalam mendidik siswa seperti menerapkan pendekatan secara arif dan bijaksana agar siswa mudah dalam memahami materi yang diajarkan. Oleh karena itu, seorang guru diharapkan dapat menuntun siswa agar dapat aktif dalam pembelajaran, sehingga siswa bukan hanya terbiasa menerima pelajaran saja, tetapi juga dapat mengembangkan ilmu yang diperoleh selama mengikuti proses pembelajaran. Upaya-upaya guru dalam mengatasi kesulitan belajar siswa, seperti mencari penyebab kesulitan belajar tersebut. Keadaan ini menuntut guru untuk melakukan pembelajaran dengan cara yang tepat da efektif karena tidak hanya menyampaikan materi secara tuntas, tetapi juga dituntut untuk dapat melakukan perubahan pada diri siswa.

Dengan adanya permasalahan ini seharusnya guru dapat mengubah gaya mengajarnya sehingga siswa merasa tertarik dan terpusat pada guru serta guru harus mampu menciptakan suasana belajar yang dapat meningkatkan motivasi peserta didik untuk turut aktif dalam kegiatan pembelajaran. Karena proses belajar dapat berlangsung dengan adanya timbal balik antara guru dan siswa karena di dalam proses pembelajaran terdapat 2 kegiatan yang saling bersinergik yaitu guru mengajar dan siswa belajar. Seperti contoh pada pembelajaran tematik kelas II Tema Pengalamanku Sub Tema Pengalamanku di Rumah. Pada pembelajaran tersebut terdapat beberapa kompetensi dasar yang harus dicapai oleh siswa. Tugas guru ialah mengajarkan bagaimana siswa harus belajar. Pada kurikulum 2013 ini, menuntut guru agar lebih kreatif dalam mengelolah pembelajaran dalam kelas sehingga membuat siswa lebih fokus dalam mengikuti pembelajaran. Oleh karena itu perlu adanya metode pembelajaran yang tepat, agar siswa mampu menerima pembelajaran yang meyenangkan sehingga siswa merasa mudah dalam menerima pembelajaran tersebut. Untuk mengatasi permasalahan tersebut guru memerlukan suatu metode atau media yang dapat di terapkan pada seluruh mata pelajaran pembelajaran tematik tersebut. Metode Think Pair Share (TPS) adalah metode yang dapat diterapkan pada siswa Sekolah Dasar pembelajaran tematik, karena dengan menggunakan metode Think Pair Share (TPS) ini diharapkan dapat memberi siswa lebih banyak waktu untuk berpikir, untuk merespon, dan saling membantu dan meningkatkan hasil belajar tematik Tema Pengalamanku Sub Tema Pengalamanku di Rumah. Dalam melaksanakan metode Think Pair Share (TPS) ini dibutuhkan kemauan dan kemampuan agar saat menyusun rencana pembelajaran dengan matang, serta membuat tugas untuk dikerjakan secara kelompok. Dikarenakan metode ini diterapkan pada kelas bawah, maka saya meminta siswa berkelompok 2 orang dalam setiap kelompoknya agar suasana pembelajaran tetap kondusif, siswa juga menjadi lebih konsentrasi.

Berdasarkan latar belakang yang telah diuraikan, maka peneliti akan mengangkat Penelitian Tindakan Kelas (PTK) yang berjudul "Peningkatan Hasil Belajar Tematik Tema Pengalamanku Menggunakan Model Kooperatif Tipe Think Pair Share (TPS) Pada Siswa Kelas II UPT. SD Negeri 03 Tabek". Berdasarkan latar belakang di atas, maka rumusan masalah pada penelitian ini adalah: 1) Bagaimana peningkatan dalam penerapan model pembelajaran kooperatif tipe Think Pair Share (TPS) pada Tema Pengalamanku Sub Tema Pengalamanku di Rumah pada siswa kelas II UPT. SD Negeri 03 Tabek? Dan 2) Bagaimana peningkatan hasil belajar tematik Tema Pengalamanku Sub Tema Pengalamanku di Rumah dengan menggunakan model \begin{tabular}{llll}
\hline EISSN 2657-0289 & Lembaga Penelitian dan Penerbitan Hasil Penelitian Ensiklopedia & 153
\end{tabular} 
pembelajaran kooperatif tipe Think Pair Share (TPS) pada siswa kelas II UPT. SD Negeri 03 Tabek?

\section{B. Metodologi Penelitian}

Jenis penelitian merupakan Penelitian Tindakan Kelas (PTK) yang kegiatannya dilaksanakan di kelas. Penelitian Tindakan Kelas merupakan suatu bentuk penelitian yang bersifat reflektif dengan melakukan tindakan-tindakan tertentu agar dapat memperbaiki dan meningkatkan praktik pembelajaran dalam kelas dengan profesional. Menurut Rochiati Wiriatmaja, (2008:12) Penelitian Tindakan Kelas (PTK) merupakan action research karena penelitian dilakukan untuk memecahkan masalah pembelajaran di kelas. Penelitian ini juga merupakan penelitian deskriptif, sebab menggambarkan bagaimana suatu teknik pembelajaran diterapkan dan bagaimana hasil yang diinginkan dapat dicapai. Penelitian ini dilaksanakan untuk memperbaiki mutu pembelajaran. Dalam penelitian ini, peneliti langsung terjun ke lapangan bersama guru dan siswa untuk melaksanakan pembelajaran. Peneliti melakukan penelitian tindakan kelas karena akan mempermudah peneliti dalam mengidentifikasi permasalahan yang terjadi selama proses pembelajaran. Selain itu, dengan melakukan penelitian tindakan kelas ini, peneliti juga dapat menemukan solusi melalui kondisi nyata dalam kelas dengan berbagai macam kondisi dengan metode pembelajaran yang relevan. Dalam pelaksanaan penelitian tindakan kelas ini menggunakan model Kurt Lewin yang menyatakan bahwa satu siklus terdiri dari 4 langkah pokok, yaitu: Perencanaan (Planning), Tindakan (Acting), Observasi (Observing), Refleksi (Reflecting).

\section{Hasil Dan Pembahasan \\ Hasil Penelitian}

Pada bab ini dijelaskan tentang hasil penelitian yang telah dilakukan oleh guru tematik kelas II UPT. SD Negeri 03 Tabek bersama teman sejawat. Hasil penelitian diperoleh melalui observasi, wawancara, tes, dan didukung dengan dokumen yang ada. Penelitian ini dilaksanakan dalam 3 siklus.

\section{Pra Siklus}

Berdasarkan hasil pre-test tersebut, peserta didik banyak yang mendapat nilai dibawah kriteria ketuntasan minimal (KKM) yaitu 76. Dari 27 peserta didik, yang tuntas pada mata pelajaran muatan Bahasa Indonesia dan Matematika hanya 13 peserta didik, menunjukkan bahwa kondisi peserta didik yang heterogen sehingga terdapat beragam kemampuan kognitif yang menyebabkan peserta didik kesulitan menerapkan pembelajaran tematik di Sekolah. Proses penyampaian materi dari guru yang monoton membuat peserta didik cepat bosan, sehingga penggunaan strategi, model, dan media sangat dibutuhkan untuk menarik perhatian peserta didik dan menjadi aktif. Berdasarkan paparan penjelasan di atas, maka dapat disimpulkan bahwa hasil belajar pembelajaran tematik yang meliputi mata pelajaran muatan Bahasa Indonesia dan Matematika masih rendah atau masih dibawah nilai KKM. Berikut merupakan hasil nilai mata pelajaran muatan Bahasa Indonesia dan Matematika pada pembelajaran 1 subtema pengalamanku di rumah.

\section{Tabel Hasil Nilai Pra Siklus Mata Pelajaran Muatan BI dan PPKn}

\begin{tabular}{|c|c|c|c|c|c|}
\hline No & Nama Peserta Didik & KKM & Jilai & intas & elum Tuntas \\
\hline 1 & Abid Alkhalifi & 76 & 40 & & $\sqrt{ }$ \\
\hline
\end{tabular}




\begin{tabular}{|c|c|c|c|c|c|}
\hline 2 & Aldo Syabibullah & 76 & 80 & $\sqrt{ }$ & \\
\hline 3 & Amirah Rihadatul Aisy & 76 & 60 & & $\sqrt{ }$ \\
\hline 4 & Ariel Dzaka Putra & 76 & 80 & $\sqrt{ }$ & \\
\hline 5 & Arisya Qonita Arta & 76 & 80 & $\sqrt{ }$ & \\
\hline 6 & Assyifa Nurdalillah & 76 & 80 & $\sqrt{ }$ & \\
\hline 7 & Azahra Qolbi Arori & 76 & 60 & & $\sqrt{ }$ \\
\hline 8 & Cellora Riskato Putri & 76 & 80 & $\sqrt{ }$ & \\
\hline 9 & Furkon Khaliq & 76 & 30 & & $\sqrt{ }$ \\
\hline 10 & Genki Alfadhla & 76 & 80 & $\sqrt{ }$ & \\
\hline 11 & Haura Septiyandra & 76 & 70 & & $\sqrt{ }$ \\
\hline 12 & Hendika Pratama & 76 & 50 & & $\sqrt{ }$ \\
\hline 13 & Keza Alfaro & 76 & 80 & $\sqrt{ }$ & \\
\hline 14 & Maulana Fatir & 76 & 80 & $\sqrt{ }$ & \\
\hline 15 & Maysha Septia & 76 & 60 & & $\sqrt{ }$ \\
\hline 16 & Muhammad Alfatih & 76 & 80 & $\sqrt{ }$ & \\
\hline 17 & $\begin{array}{l}\text { Muhammad Rafit } \\
\text { Akbar }\end{array}$ & 76 & 40 & & $\sqrt{ }$ \\
\hline 18 & Muhammad Yusuf & 76 & 50 & & $\sqrt{ }$ \\
\hline 19 & M Raziqul Ihsan & 76 & 80 & $\sqrt{ }$ & \\
\hline 20 & RA. Adelio Agustino & 76 & 40 & & $\sqrt{ }$ \\
\hline 21 & Rafael Ayro Afdiali & 76 & 80 & $\sqrt{ }$ & \\
\hline 22 & Raisya Naufalia & 76 & 40 & & $\sqrt{ }$ \\
\hline 23 & Raisyah Apriliana Neza & 76 & 80 & $\sqrt{ }$ & \\
\hline 24 & Refan Saputra & 76 & 50 & & $\sqrt{ }$ \\
\hline 25 & Safiratul Rahmah & 76 & 90 & $\sqrt{ }$ & \\
\hline 26 & Uthari Sri Anggaraini & 76 & 30 & & $\sqrt{ }$ \\
\hline 27 & Zaky Subuh Alfatih & 76 & 70 & & $\sqrt{ }$ \\
\hline Jumlah & 1740 & 13 & 14 & & \\
\hline Nilai rata-rata & 64,44 & & & & \\
\hline Persentase & $48,15 \%$ & $51,85 \%$ & & & \\
\hline
\end{tabular}

Berdasarkan tabel di atas, dapat diketahui bahwa nilai rata-rata hasil belajar peserta didik kelas II mata pelajaran muatan Bahasa Indonesia dan Matematika pembelajaran 1 subtema pengalamanku di rumah adalah 64,44. Dari 27 peserta didik, hanya 13 peserta didik yang mencapai KKM dengan prosentase ketuntasan $48,15 \%$. 


\section{Deskripsi Hasil Penelitian Siklus I}

Tahap lanjutan dari pra siklus adalah tahap siklus I. Pada tahap ini terdiri dari 4 (empat) tahap, yakni: perencanaan, pelaksanaan, observasi, dan juga refleksi. Berikut ini merupakan hasil belajar Pembelajaran 1 Sub Tema Pengalamanku di Rumah kelas II UPT. SD Negeri 03 Tabek menggunakan model pembelajaran kooperatif tipe Think Pair Share (TPS) pada siklus I. Adapun data hasil belajar pada siklus I kelas II UPT. SD Negeri 03 Tabek pada Sub Tema Pengalamanku di Rumah Pembelajaran 1 mata pelajaran muatan Bahasa Indonesia dan Matematika adalah sebagai berikut:

\section{Tabel Hasil Nilai Siklus I Mata Pelajaran Muatan BI dan Matematika}

\begin{tabular}{|c|c|c|c|c|c|}
\hline No & Nama Peserta Didik & KKM & Nilai & Cuntas & $\begin{array}{l}\text { Belum } \\
\text { Tuntas }\end{array}$ \\
\hline 1 & Abid Alkhalifi & 76 & 40 & & $\sqrt{ }$ \\
\hline 2 & Aldo Syabibullah & 76 & 80 & $\sqrt{ }$ & \\
\hline 3 & Amirah Rihadatul Aisy & 76 & 70 & & $\sqrt{ }$ \\
\hline 4 & Ariel Dzaka Putra & 76 & 80 & $\sqrt{ }$ & \\
\hline 5 & Arisya Qonita Arta & 76 & 90 & $\sqrt{ }$ & \\
\hline 6 & Assyifa Nurdalillah & 76 & 80 & $\sqrt{ }$ & \\
\hline 7 & Azahra Qolbi Arori & 76 & 70 & & $\sqrt{ }$ \\
\hline 8 & Cellora Riskato Putri & 76 & 80 & $\sqrt{ }$ & \\
\hline 9 & Furkon Khaliq & 76 & 40 & & $\sqrt{ }$ \\
\hline 10 & Genki Alfadhla & 76 & 80 & $\sqrt{ }$ & \\
\hline 11 & Haura Septiyandra & 76 & 80 & $\sqrt{ }$ & \\
\hline 12 & Hendika Pratama & 76 & 60 & & $\sqrt{ }$ \\
\hline 13 & Keza Alfaro & 76 & 80 & $\sqrt{ }$ & \\
\hline 14 & Maulana Fatir & 76 & 80 & $\sqrt{ }$ & \\
\hline 15 & Maysha Septia & 76 & 70 & & $\sqrt{ }$ \\
\hline 16 & Muhammad Alfatih & 76 & 80 & $\sqrt{ }$ & \\
\hline 17 & Muhammad Rafit Akbar & 76 & 50 & & $\sqrt{ }$ \\
\hline 18 & Muhammad Yusuf & 76 & 60 & & $\sqrt{ }$ \\
\hline 19 & M Raziqul Ihsan & 76 & 80 & $\sqrt{ }$ & \\
\hline 20 & RA. Adelio Agustino & 76 & 50 & & $\sqrt{ }$ \\
\hline 21 & Rafael Ayro Afdiali & 76 & 80 & $\sqrt{ }$ & \\
\hline 22 & Raisya Naufalia & 76 & 50 & & $\sqrt{ }$ \\
\hline 23 & Raisyah Apriliana Neza & 76 & 90 & $\sqrt{ }$ & \\
\hline 24 & Refan Saputra & 76 & 60 & & $\sqrt{ }$ \\
\hline 25 & Safiratul Rahmah & 76 & 100 & $\sqrt{ }$ & \\
\hline 26 & Uthari Sri Anggaraini & 76 & 40 & & $\sqrt{ }$ \\
\hline
\end{tabular}




\begin{tabular}{|l|c|c|c|c|}
\hline \multicolumn{1}{|c|}{27} & Zaky Subuh Alfatih & 76 & 80 & $\sqrt{ }$ \\
\hline Jumlah & 1900 & 15 & 12 & \\
\hline $\begin{array}{l}\text { Nilai rata- } \\
\text { rata }\end{array}$ & 70,37 & & & \\
\hline Persentase & $55,56 \%$ & $44,44 \%$ & & \\
\hline
\end{tabular}

Dari data pada tabel dapat diketahui jumlah persentase ketuntasan pada siklus I subtema pengalamanku di rumah pembelajaran 1 mata pelajaran muatan Bahasa Indonesia dan matematika adalah 55,56\% sehingga dapat diperoleh nilai rata-rata kelas sebesar 70,37 Maka, dengan diadakannya tindakan pada siklus I menggunakan model kooperatif tipe Think Pair Share (TPS) terdapat peningkatan hasil belajar dibandingkan dengan hasil nilai Pre-test yang hanya mendapat nilai rata-rata kelas sebesar 64,44. Kemudian dari pra siklus sampai siklus I kelas II UPT. SD Negeri 03 Tabek mengalami peningkatan prosentase ketuntasan dari 48,15\%. menjadi 55,56\%. Nilai rata-rata pada siklus I ini belum mencapai mencapai KKM $\geq 76$ selain itu, prosentase ketutasan siswa masih belum mencapai ketercapaian indikator kinerja yang ditetapkan peneliti yakni dengan prosentase $85 \%$.

Berdasarkan perhitungan perolehan nilai pada aktivitas guru di atas, maka dapat disimpulkan bahwa aktivitas guru dalam siklus I ini dikatakan belum tuntas dikarenakan belum mencapai skor minimal yaitu 85\%. Pelaksanaan tindakan pada siklus I ini telah dilaksanakan sesuai dengan RPP. Namun ada beberapa langkahlangkah pembelajaran yang kurang maksimal. Meskipun hasil ketuntasan pembelajaran 1 subtema pengalamanku di rumah belum mencapai kriteria ketuntasan siswa yang diharapkan, tetapi jika dibandingkan dengan hasil dari pembelajaran sebelumnya yang belum memakai model pembelajaran kooperatif tipe Think Pair Share (TPS), sudah mengalami peningkatan pada siklus I ini. Setelah melakukan proses pembelajaran, observer beserta peneliti berdiskusi untuk merumuskan beberapa hal yang perlu diperbaiki untuk pelaksanaan tindakan siklus II.

Berikut merupakan hasil diskusi antara peneliti dan observer: 1) Ada beberapa aktivitas guru yang dinilai kurang maksimal sehingga perlu ditindak lanjuti. Seperti guru terlalu capat dalam berbicara sehingga beberapa siswa merasa kebingungan, guru tidak meminta semua kelompok untuk mempresentasikan hasil diskusinya, kemudian guru juga tidak sempat memeriksa hasil kerja individu siswa dikarenakan keterbatasan waktu, selain itu, guru juga kurang fokus sehingga beberapa siswa asik berbicara sendiri; 2) Ada beberapa aktivitas siswa yag dinilai kurang maksimal. Seperti pada saat guru melakukan apersepsi, siswa kurag aktif dalam menanggapi pertanyaan dari guru. Selain itu, pada saat siswa megerjakan tugas individu, tidak sedikit siswa yang contekan; 3) Guru dikatakan masih belum maksimal dalam memberi motivasi kepada siswa sehingga banyak dari mereka ketika proses pembelajaran berlangsung kurang fokus dan ramai sendiri.

Berdasarkan pemaparan hasil diskusi peneliti dan observer, dapat disimpulkan hal-hal yang perlu diperbaiki untuk pelaksanaan siklus II agar mendapat hasil yang maksimal, adalah: 1) Memaksimalkan aktivitas guru sehingga guru dapat mengoptimalkan aktivitasnya yang kurang maksimal pada siklus I; 2) Guru lebih kreatif dalam membangkitkan semangat siswa agar siswa tidak merasa bosan; 3) Menghadirkan kelas yang aktif, seperti memberi media yang membuat siswa penasaran sehingga siswa dapat antusias dalam mengikuti pembelajaran; 4) 
Memberikan perhatian kepada siswa yang ramai dengan mengajak siswa tersebut duduk di bangku yang dekat dengan guru, agar pengawasan lebih mudah.

\section{Deskripsi Hasil Penelitian Siklus II}

Berikut ini merupakan hasil belajar pembelajaran 2 subtema pengalamanku di rumah di UPT.SD Negeri 03 Tabek menggunakan model pembelajaran kooperatif tipe Think Pair Share (TPS) pada siklus II. Adapun data hasil belajar pada siklus II subtema pengalamnku di rumah pada pembelajaran 2 mata pelajaran muatan PPKn dan SBdP adalah sebagai berikut:

Tabel Hasil Nilai Siklus II Mata Pelajaran Muatan PPKn dan SBdP

\begin{tabular}{|c|c|c|c|c|c|}
\hline No & Nama Peserta Didik & కKM & Jilai & untas & $\begin{array}{l}\text { Belum } \\
\text { Tuntas }\end{array}$ \\
\hline 1 & Abid Alkhalifi & 76 & 50 & & $\sqrt{ }$ \\
\hline 2 & Aldo Syabibullah & 76 & 80 & $\sqrt{ }$ & \\
\hline 3 & Amirah Rihadatul Aisy & 76 & 80 & $\sqrt{ }$ & \\
\hline 4 & Ariel Dzaka Putra & 76 & 80 & $\sqrt{ }$ & \\
\hline 5 & Arisya Qonita Arta & 76 & 90 & $\sqrt{ }$ & \\
\hline 6 & Assyifa Nurdalillah & 76 & 90 & $\sqrt{ }$ & \\
\hline 7 & Azahra Qolbi Arori & 76 & 80 & $\sqrt{ }$ & \\
\hline 8 & Cellora Riskato Putri & 76 & 80 & $\sqrt{ }$ & \\
\hline 9 & Furkon Khaliq & 76 & 40 & & $\sqrt{ }$ \\
\hline 10 & Genki Alfadhla & 76 & 80 & $\sqrt{ }$ & \\
\hline 11 & Haura Septiyandra & 76 & 80 & $\sqrt{ }$ & \\
\hline 12 & Hendika Pratama & 76 & 70 & & $\sqrt{ }$ \\
\hline 13 & Keza Alfaro & 76 & 90 & $\sqrt{ }$ & \\
\hline 14 & Maulana Fatir & 76 & 80 & $\sqrt{ }$ & \\
\hline 15 & Maysha Septia & 76 & 80 & $\sqrt{ }$ & \\
\hline 16 & Muhammad Alfatih & 76 & 80 & $\sqrt{ }$ & \\
\hline 17 & Muhammad Rafit Akbar & 76 & 60 & & $\sqrt{ }$ \\
\hline 18 & Muhammad Yusuf & 76 & 80 & $\sqrt{ }$ & \\
\hline 19 & M Raziqul Ihsan & 76 & 80 & $\sqrt{ }$ & \\
\hline 20 & RA. Adelio Agustino & 76 & 60 & & $\sqrt{ }$ \\
\hline 21 & Rafael Ayro Afdiali & 76 & 90 & $\sqrt{ }$ & \\
\hline 22 & Raisya Naufalia & 76 & 50 & & $\sqrt{ }$ \\
\hline 23 & Raisyah Apriliana Neza & 76 & 100 & $\sqrt{ }$ & \\
\hline 24 & Refan Saputra & 76 & 60 & & $\sqrt{ }$ \\
\hline 25 & Safiratul Rahmah & 76 & 90 & $\sqrt{ }$ & \\
\hline
\end{tabular}




\begin{tabular}{|l|c|c|c|c|c|}
\hline \multicolumn{1}{|c|}{26} & Uthari Sri Anggaraini & 76 & 40 & & $\sqrt{ }$ \\
\hline \multicolumn{1}{|c|}{27} & Zaky Subuh Alfatih & 76 & 80 & $\sqrt{ }$ & \\
\hline Jumlah & 2020 & 19 & 8 & & \\
\hline $\begin{array}{l}\text { Nilai rata- } \\
\text { rata }\end{array}$ & 74,81 & & & & \\
\hline Persentase & $70,37 \%$ & $\begin{array}{c}29,6 \\
3 \%\end{array}$ & & & \\
\hline
\end{tabular}

Dari data pada tabel dapat diketahui jumlah total keseluruhan nilai pada siklus II Sub Tema Pengalamanku di Rumah Pembelajaran 2 mata pelajaran muatan PPKn dan SBdP adalah 2020, sehingga dapat diperoleh nilai rata-rata kelas sebesar 74,81. Maka, dengan diadakannya tindakan pada siklus II menggunakan model kooperatif tipe Think Pair Share (TPS) terdapat peningkatan hasil belajar dibandingkan dengan hasil nilai siklus I yang hanya mendapat nilai rata-rata kelas sebesar 70,37. Kemudian dari siklus I sampai siklus II kelas II UPT.SD Negeri 03 Tabek mengalami peningkatan prosentase ketuntasan dari $.55,56 \%$ menjadi $70,37 \%$ Meskipun nilai rata-rata sudah mencapai $\mathrm{KKM} \geq 76$. Selain itu, prosentase ketutasan siswa belum mencapai ketercapaian indikator kinerja yang ditetapkan peneliti bersama observer yakni dengan prosentase $85 \%$.

Pada tahap ini aka dikaji apa saja yang telah dilakukan pada siklus II ini untuk megetahui keberhasilan dalam penerapan model kooperatif tipe Think Pair Share (TPS). Berikut merupakan hasil refleksu pada siklus II: 1) Dari data observasi guru pada siklus II mengenai aktivitas pembelajaran. Guru sudah mampu menguasai dan mengkondisikan siswa agar dapat lebih aktif dalam pembelajaran. Sebagian kendala pada siklus I telah diperbaiki pada proses tindakan siklus II. Pada lembar observasi guru, maka dapat disimpulkan bahwa guru belum sempurna melaksanakan kegiatan pembelajaran. Keberhasilan tersebut dibuktikan dengan adanya peningkatan hasil observasi guru yaitu 71 dari siklus I manjadi 80 dari siklus II; 2) Dari data observasi siswa dapat disimpulkan bahwa siswa lebih mudah dalam memahami materi dengan menggunakan model kooperatif tipe Think Pair Share (TPS) pada saat proses pembelajaran. Siswa mampu bekerja sama dalam satu kelompok yang tingkat kognitifnya berbeda. Hal ini dibuktikan dengan adanya peningkatan dari siklus I 69,32\%. dan pada siklus II naik menjadi 82,95\%; dan 3) Berdasarkan analisis data, diperoleh hasil bahwa pembelajaran dengan menggunakan model kooperatif tipe Think Pair Share (TPS) dapat meningkatkan hasil belajar subtema pengalamanku di rumah. Hal tersebut dibuktikan pada rata-rata nilai dan prosentase ketuntasan siswa pada mata pelajaran subtema pengalamanku di rumah. Peningkatan rata-rata hasil belajar dapat dilihat pada table sebagai berikut:

Tabel Peningkatan Rata-rata dan persentase ketuntasan Hasil Belajar Siswa

\begin{tabular}{|c|c|c|c|}
\hline \multirow{2}{*}{ Tindakan } & \multirow{2}{*}{ Nilai rata - rata } & Persentase & \\
\cline { 3 - 4 } & 70,37 & Tuntas & Belum Tuntas \\
\hline Siklus I & 74,81 & $55,56 \%$ & $44,44 \%$ \\
\hline Siklus II & $70,37 \%$ & $29,63 \%$ \\
\hline
\end{tabular}

Berdasarkan peningkatan observasi guru dan siswa serta hasil belajar siswa pada subtema pengalamanku di rumah pada pembelajaran 2, maka peneliti dan observer memutuskan untuk melanjutkan pada tindakan berikutnya atau siklus III. 


\section{Deskripsi Hasil Penelitian Siklus III}

Berikut ini merupakan hasil belajar pembelajaran 3 subtema pengalamanku di rumah di UPT.SD Negeri 03 Tabek menggunakan model pembelajaran kooperatif tipe Think Pair Share (TPS) pada siklus III. Adapun data hasil belajar pada siklus III Sub Tema Pengalamanku di Rumah pada pembelajaran 3 mata pelajaran muatan Bahasa Indonesia dan Matematika adalah sebagai berikut:

Tabel Hasil Nilai Siklus III Mata Pelajaran Muatan BI dan Matematika

\begin{tabular}{|c|c|c|c|c|c|}
\hline No & Nama Peserta Didik & KKM & Nilai & untas & elum Tuntas \\
\hline 1 & Abid Alkhalifi & 76 & 70 & & $\sqrt{ }$ \\
\hline 2 & Aldo Syabibullah & 76 & 80 & $\sqrt{ }$ & \\
\hline 3 & $\begin{array}{l}\text { Amirah Rihadatul } \\
\text { Aisy }\end{array}$ & 76 & 80 & $\sqrt{ }$ & \\
\hline 4 & Ariel Dzaka Putra & 76 & 90 & $\sqrt{ }$ & \\
\hline 5 & Arisya Qonita Arta & 76 & 100 & $\sqrt{ }$ & \\
\hline 6 & Assyifa Nurdalillah & 76 & 100 & $\sqrt{ }$ & \\
\hline 7 & Azahra Qolbi Arori & 76 & 80 & $\sqrt{ }$ & \\
\hline 8 & Cellora Riskato Putri & 76 & 90 & $\sqrt{ }$ & \\
\hline 9 & Furkon Khaliq & 76 & 50 & & $\sqrt{ }$ \\
\hline 10 & Genki Alfadhla & 76 & 80 & $\sqrt{ }$ & \\
\hline 11 & Haura Septiyandra & 76 & 80 & $\sqrt{ }$ & \\
\hline 12 & Hendika Pratama & 76 & 80 & $\sqrt{ }$ & \\
\hline 13 & Keza Alfaro & 76 & 100 & $\sqrt{ }$ & \\
\hline 14 & Maulana Fatir & 76 & 90 & $\sqrt{ }$ & \\
\hline 15 & Maysha Septia & 76 & 80 & $\sqrt{ }$ & \\
\hline 16 & Muhammad Alfatih & 76 & 90 & $\sqrt{ }$ & \\
\hline 17 & $\begin{array}{l}\text { Muhammad Rafit } \\
\text { Akbar }\end{array}$ & 76 & 80 & $\sqrt{ }$ & \\
\hline 18 & Muhammad Yusuf & 76 & 80 & $\sqrt{ }$ & \\
\hline 19 & M Raziqul Ihsan & 76 & 90 & $\sqrt{ }$ & \\
\hline 20 & RA. Adelio Agustino & 76 & 80 & $\sqrt{ }$ & \\
\hline 21 & Rafael Ayro Afdiali & 76 & 100 & $\sqrt{ }$ & \\
\hline 22 & Raisya Naufalia & 76 & 80 & $\sqrt{ }$ & \\
\hline 23 & $\begin{array}{l}\text { Raisyah Apriliana } \\
\text { Neza }\end{array}$ & 76 & 100 & $\sqrt{ }$ & \\
\hline 24 & Refan Saputra & 76 & 80 & $\sqrt{ }$ & \\
\hline 25 & Safiratul Rahmah & 76 & 100 & $\sqrt{ }$ & \\
\hline 26 & Uthari Sri Anggaraini & 76 & 60 & & $\sqrt{ }$ \\
\hline
\end{tabular}




\begin{tabular}{|l|c|c|c|c|c|}
\hline \multicolumn{1}{|c|}{27} & Zaky Subuh Alfatih & 76 & 80 & $\sqrt{ }$ & \\
\hline Jumlah & 2270 & 24 & 3 & & \\
\hline Nilai rata-rata & 84,07 & & & & \\
\hline Persentase & $88,89 \%$ & $\begin{array}{c}11,11 \\
\%\end{array}$ & & & \\
\hline
\end{tabular}

Dari data pada tabel dapat diketahui jumlah total keseluruhan nilai pada siklus III Sub Tema pengalamanku di Rumah pembelajaran 3 mata pelajaran muatan Bahasa Indonesia dan Matematika adalah 2270, sehingga dapat diperoleh nilai rata-rata kelas sebesar 84,07. Maka, dengan diadakannya tindakan pada siklus III menggunakan model kooperatif tipe Think Pair Share (TPS) terdapat peningkatan hasil belajar dibandingkan dengan hasil nilai siklus II yang hanya mendapat nilai rata-rata kelas sebesar 74,81. Kemudian dari siklus II sampai siklus III kelas II UPT.SD Negeri 03 Tabek mengalami peningkatan prosentase ketuntasan dari 70,37\% menjadi 88,89\% Meskipun nilai rata-rata sudah mencapai $\mathrm{KKM} \geq 76$. Selain itu, prosentase ketutasan siswa sudah mencapai ketercapaian indikator kinerja yang ditetapkan peneliti bersama observer yakni dengan prosentase $85 \%$.

Pada tahap ini aka dikaji apa saja yang telah dilakukan pada siklus III ini untuk megetahui keberhasilan dalam penerapan model kooperatif tipe Think Pair Share (TPS). Berikut merupakan hasil refleksu pada siklus III: 1) Dari data observasi guru pada siklus III mengenai aktivitas pembelajaran. Guru sudah mampu menguasai dan mengkondisikan siswa agar dapat lebih aktif dalam pembelajaran. Sebagian kendala pada siklus II telah diperbaiki pada proses tindakan siklus III. Pada lembar observasi guru, maka dapat disimpulkan bahwa guru sudah sempurna melaksanakan kegiatan pembelajaran. Keberhasilan tersebut dibuktikan dengan adanya peningkatan hasil observasi guru yaitu 80 dari siklus II manjadi 90 dari siklus III; 2) Dari data observasi siswa dapat disimpulkan bahwa siswa lebih mudah dalam memahami materi dengan menggunakan model kooperatif tipe Think Pair Share (TPS) pada saat proses pembelajaran. Siswa mampu bekerja sama dalam satu kelompok yang tingkat kognitifnya berbeda. Hal ini dibuktikan dengan adanya peningkatan dari siklus II $82,95 \%$ dan pada siklus III naik menjadi 90,91\%; dan 3) Berdasarkan analisis data, diperoleh hasil bahwa pembelajaran dengan menggunakan model kooperatif tipe Think Pair Share (TPS) dapat meningkatkan hasil belajar Sub Tema Pengalamanku di Rumah. Hal tersebut dibuktikan pada rata-rata nilai dan prosentase ketuntasan siswa pada mata pelajaran Sub Tema Pengalamanku di Rumah. Peningkatan rata-rata hasil belajar dapat dilihat pada table sebagai berikut:

Tabel Peningkatan Rata-rata dan persentase ketuntasan Hasil Belajar Siswa

\begin{tabular}{|c|c|c|c|}
\hline \multirow{2}{*}{ Tindakan } & \multirow{2}{*}{ Nilai rata - rata } & Persentase & \\
\cline { 3 - 4 } & 70,37 & Tuntas & Belum Tuntas \\
\hline Siklus I & 74,81 & $55,56 \%$ & $44,44 \%$ \\
\hline Siklus II & 84,07 & $70,37 \%$ & $29,63 \%$ \\
\hline Siklus III & $88,89 \%$ & $11,11 \%$ \\
\hline
\end{tabular}

Peningkatan Rata-rata dan persentase ketuntasan Hasil Belajar Siswa pada mata pelajaran Sub Tema Pengalamanku di Rumah. Peningkatan rata-rata hasil belajar dapat dilihat pada diagram di bawah ini: Berdasarkan peningkatan observasi guru dan siswa serta hasil belajar siswa pada Sub Tema Pengalamanku di Rumah pada pembelajaran 
3, maka peneliti dan observer memutuskan untuk tidak melanjutkan pada tindakan berikutnya.

\section{Penerapan model pembelajaran kooperatif tipe Think Pair Share (TPS) pada subtema pengalamanku di rumah pada siswa kelas II UPT.SD Negeri 03 Tabek.}

Model pembelajaran kooperatif tipe Think Pair Share (TPS) dilaksanakan dengan cara berkelompok kecil/ berpasangan dengan kemampuan siswa yang berbedabeda sehingga dapat bekerja sama untuk menyelesaikan tujuan pembelajaran. Dalam penerapan model ini pada siklus I, siklus II dan siklus III peneliti memperoleh hasil yang berbeda. Penerapan model kooperatif tipe Think Pair Share (TPS) pada pembelajaran 3 Sub Tema Pengalamanku di Rumah pada kelas II UPT.SD Negeri 03 Tabek dapat dikatakan berhasil karena terdapat peningkatan aktivitas.guru dan siswa dari siklus I, siklus II dan siklus III. Peningkatan tersebut dapat disimpulkan dalam diagram berikut: Dari diagram di atas, dapat diketahui bahwa aktivitas guru pada siklus I, siklus II dan siklus III mengalami peningkatan. Pada siklus I memperoleh nilai sebesar $72 \%$ dan hasil tersebut dikatakan belum tuntas karena belum mencapai kriteria minimal yakni $85 \%$. Tidak maksimalnya aktivitas guru disebabkan oleh beberapa faktor seperti guru terlalu cepat dalam berbicara, guru kurang fokus dalam mengajar dan lain sebagainya. Sedangkan pada siklus II diperoleh hasil sebesar $80 \%$, dibanding dengan siklus I, pada siklus II ini terdapat peningkatan dan belum dapat dikatakan berhasil dikarenakan belum mencapai keberhasilan dalam proses pembelajaran belum dikatakan tuntas dikarenakan belum mencapai skor minimal yaitu $85 \%$. Sedangkan pada siklus III diperoleh hasil sebesar 90\%, dibanding dengan siklus II, pada siklus III ini terdapat peningkatan dan sudah dapat dikatakan berhasil dikarenakan sudah mencapai keberhasilan dalam proses pembelajaran sudah dikatakan tuntas dikarenakan sudah mencapai skor minimal yaitu $85 \%$. Keberhasilan dalan tindakan pada siklus III ini dikarenakan adanya evaluasi pada siklus II sehingga lebih dimaksimalkan pada siklus III seperti pada penyampaian materi yang lebih tenang dan pelan-pelan

Dari diagram di atas, dapat diketahui bahwa terjadi peningkatan dari siklus I, siklus II dan siklus III. Pada siklus I memperoleh nilai sebesar 69,32\%. Hasil tersebut dikatakan belum tuntas karena tidak memenuhi kriteria minimum yakni 85 . Proses pembelajaran pada siklus I, siswa kurang aktif saat diberi pertanyaan, siswa juga sering berbicara sendiri saat proses pembelajaran. Sedangkan pada siklus II memperoleh nilai sebesar 82,95 dan belum dapat dikatakan tuntas atau berhasil karena belum mencapai kriteria minimal yakni $85 \%$. Sedangkan pada siklus III diperoleh hasil sebesar 90,91\%, dibanding dengan siklus II, pada siklus III ini terdapat peningkatan dan sudah dapat dikatakan berhasil dikarenakan sudah mencapai keberhasilan dalam proses pembelajaran sudah dikatakan tuntas dikarenakan sudah mencapai skor minimal yaitu $85 \%$. Secara keseluruhan siswa dapat mengikuti pembelajaran dengan baik seperti dalam bekerja sama kelompok ataupun keaktifannya. Hal ini sesuai dengan kelebihan model kooperatif yaitu suasana kegembiraan akan tumbuh dalam proses pembelajaran, kerja sama antar siswa tercipta dengan dinamis, munculnya dinamika gotong royong yang merata pada seluruh siswa. Menghindari kejenuhan siswa dalam mengikuti pembelajaran, karena siswa terlibat langsung dalam menjawab soal yang disampaikan kepadanya melalui media. Hal ini karena fungsi media adalah sebagai alat bantu dalam proses pembelajaran untuk 
mempermudah siswa dalam memahami materi sehingga dapat mempertinggi daya serap siswa terhadap materi pembelajaran.

\section{Peningkatan Hasil Belajar Tematik subtema pengalamanku di rumah dengan menggunakan model pembelajaran kooperatif tipe Think Pair Share (TPS) pada siswa kelas II UPT.SD Negeri 03 Tabek.}

Dalam penelitian tindakan kelas (PTK) yang telah dilakukan sejak pra siklus, siklus I, siklus II, dan siklus III mendapat hasil yang meningkat. Hasil belajar selalu meningkat pada setiap siklusnya. Pada tindakan siklus I siklus II, dan III, peneliti menerapkan model kooperatif tipe Think Pair Share (TPS). Berikut akan diuraikan hasil ketuntasan siswa pada setiap siklusnya: Pra Siklus. Pada saat peneliti mengajar di UPT.SD Negeri 03 Tabek diketahui bahwa nilai pada Pembelajaran 1 Sub Tema Pengalamanku di Rumah ini sangat rendah nilai rata - rata adalah 64,44. Dari 27 peserta didik, hanya 13 peserta didik yang mencapai KKM dengan prosentase ketuntasan 48,15\%. Siklus I. Pada siklus I peneliti menerapkan model kooperatif tipe Think Pair Share (TPS) di kelas II UPT.SD Negeri 03 Tabek untuk meningkatkan hasil belajar siswa pada Sub Tema Pengalamanku di Rumah pada Pembelajaran 1. Mata pelajaran muatan Bahasa Indonesia dan Matematika dari pra siklus memperoleh 48,15\%. menjadi 55,56\% pada siklus I. Berdasarkan nilai KKM pada mata pelajaran tematik yaitu 76 sehingga dapat diketahui dari jumlah 27 siswa pada pembelajaran 1 subtema pengalamanku di rumah terdapat 15 siswa tuntas dan 12 siswa belum tuntas. Siklus II. Pada siklus II ini, hasil belajar pada pembelajaran 2. Mata pelajaran muatan PPKn dan SBdP dari siklus I memperoleh 55,56\%. menjadi 70,37\%. Pada siklus II, Berdasarkan nilai KKM pada mata pelajaran tematik yaitu 76 sehingga dapat diketahui dari jumlah 27 siswa pada Pembelajaran 2 Sub Tema Pengalamanku di Rumah terdapat 19 siswa tuntas dan 8 siswa belum tuntas. Siklus III. Pada siklus III ini, hasil belajar pada pembelajaran 3. Mata pelajaran muatan Bahasa Indonesia dan Matematika dari siklus II memperoleh 70,37\%. menjadi 88,89\%. Pada siklus III. Berdasarkan nilai KKM pada mata pelajaran tematik yaitu 76 sehingga dapat diketahui dari jumlah 27 siswa pada pembelajaran 3 Sub Tema Pengalamanku di Rumah terdapat 24 siswa tuntas dan 3 siswa belum tuntas,

\section{Penutup}

Berdasarkan hasil penelitian dan pembahasan tentang peningkatan hasil belajar Pembelajaran Sub Tema Pengalamanku di Rumah dengan menerapkan model pembelajaran kooperatif tipe Think Pair Share (TPS) pada kelas II UPT.SD Negeri 03 Tabek, maka dapat ditarik kesimpulan sebagai berikut: Penerapan model kooperatif tipe Think Pair Share (TPS) pada Pembelajaran Sub Tema Pengalamanku di Rumah dapat dikategorikan sangat baik, terbukti dari peningkatan nilai hasil observasi aktivitas guru yang pada siklus I hanya mencapai 72, siklus II meningkat menjadi 80, sedangkan pada siklus III meningkat menjadi 90. Begitu juga dengan nilai hasil observasi peserta didik yang pada siklus I sebesar 69,32 meningkat menjadi 82,95 pada siklus II dan meningkat menjadi 90,91 pada siklus III. Serta dapat disimpulkan bahwa guru dan peserta didik mampu menerapkan model pembelajaran kooperatif tipe Think Pair Share (TPS) dengan sangat baik. Model pembelajaran kooperatif tipe Think Pair Share (TPS) dapat meningkatkan hasil belajar Sub Tema Pengalamanku di Rumah pada siswa kelas II UPT.SD Negeri 03 Tabek. Hal tersebut dapat dilihat dari nilai rata-rata siswa pada kondisi awal yakni sebesar 64,44 prosentasi 48,15\%, pada siklus I terjadi peningkatan menjadi 70,37 prosentase 55,56\%, pada siklus II kembali EISSN 2657-0289 Lembaga Penelitian dan Penerbitan Hasil Penelitian Ensiklopedia $\quad 163$ 
terjadi peningkatan menjadi 74,81 prosentase $70,37 \%$ dan pada siklus III kembali terjadi peningkatan menjadi 84,07 prosentase $88,89 \%$.

\section{Daftar Pustaka}

Hamdayana, Jumannta. 2014. Model dan Metode Pembelajaran Kreatif dan Berkarakter. (Bogor: PT Ghalia Indonesia).

Khodijah, Nyayu. 2014. Psikologi Pendidikan. (Jakarta: PT Grafindo Persada).

Majid, Abdul. 2014. Strategi Pembelajaran. (Bandung: PT Remaja Rosdakarya).

Rusman. 2012. Model-model Pembelajaran. (Jakarta: PT Raja Grafindo Persada).

Sihabuddin. 2014. Strategi Pembelajaran. (Surabaya: UIN Sunan Ampel Press).

Sudijono, Anas. 2006. Pengantar Evaluasi Pendidikan. (Jakarta: PT Grafindo Persada).

Supardi. 2015. Penilaian Autentik Pembelajaran Afektif, Kognitif, dan Psikomotorik. (Jakarta: PT Raja Grafindo Persada).

Suprijono.Agus, (2016), Cooperative Learning Teori dan Aplikasi Paikem,

Trianto. 2010. Mendesain Model Pembelajaran Inovatif-Progresif. (Jakarta: Kencana).

Wiriatmaja, Rochiati. 2008. Metode Penelitian Tindakan Kelas. (Bandung: Remaja Rosda Karya). 